\title{
RESEARCH OF HYDROTHERMAL PROCESSING OF DRY BARLEY MALT
}

\begin{abstract}
Annotation moisture regimes. active substances. swelling, hydro module.

\section{Introduction}

Functional properties of food products today have become the subject of increased attention of food industry specialists. Perspective is those food technologies that allow not only meet the human needs for essential nutrients, but also perform wellness functions and have biologically active substances in their composition. The derived raw material for the production of various food products is a germinated grain of different crops. Such a grain has in its composition a sufficient amount of antioxidants, which have the ability to reduce the rate of oxidative processes. In addition, during the germination process, the enzyme systems are activated in the grain and complex components are split into simpler ones that are easily absorbed by the human body [1-2].
\end{abstract}

Functional properties of food products with the addition of germinated grain raw materials have become the object of increased attention of scientists and specialists in the food industry. In addition to the nutritional ingredients, food products with the addition of grain raw materials contain functional ingredients that positively affect the human body that helps to adapt to the effects of the external environment. Functional products with the addition of germinated grain are considered not only as a source of plastic substances and energy but also as a nutritional complex that provides a healing effect.

The usage of germinated grain in the food and processing industries is very limited due to its short shelf life and the characteristics of preparing malt for further processing. A relevant technological challenge is the selection of barley malt

The cycle of researches concerning hydrothermal processing of dry barley malt has been carried out. The purpose of determining the optimal technological regimes of hydrothermal processing of dry germinated grain is the prospects for its further use in various food technologies as a food additive or a component of the enrichment of products with biologically

The work highlights the selection process and the main technological parameters of the process that can be used in the industrial processing of barley malt. As a research object, dry germinated grain (malt) produced by a special technology was used. In the course of research, an optimal hydro module was selected for humidifying barley malt, the temperature regime of hydrothermal processing of germinated grain was determined, the degree of swelling of malted grain was determined, the optimum time of wetting of raw materials for its further processing was determined.

When analyzing the data obtained, it was concluded that the optimal hydro module for swelling barley malt is 1:4, the optimum temperature is $+65{ }^{\circ} \mathrm{C}$ and the duration of hydrothermal processing is 48 hours. The regimes of hydrothermal processing of barley malt presented in the article will allow optimizing the technological process of malt processing.

Keywords: barley, malt, germinated grains, moisture, hydrothermal processing, the degree of swelling, the rate of

\section{Literature review}

The usage of germinated grain in the food and processing industries is very limited due to its short shelf life. Storage of malt is possible only if it is dried to $4-6 \%$ [3-4]. Dry storage of malt allows expanding the range of its use in the production of various food products. Thus, during further processing of malt, it must be moistened; therefore, the study of the hydrothermal processing of dry germinated grain and the selection of the optimal parameters of this process is a very topical technological task that needs to be studied more deeply.
During the hydrothermal processing of barley grain, the process of moisture distribution occurs in accordance with the thermodynamic characteristics of moisture transfer in the main anatomical parts of the grain [5].

The porous structure of the fruit coat of a grain has the ability to absorb moisture with which the grain contacts quickly. However, the coat can not retain moisture. This function is performed by the seed coat, especially, the aleurone layer of the endosperm and the embryo itself. So the water absorption capacity and the rate of moisture absorption by grain are due to the factors which are given in Fig. 1.

Firstly, the grain intensively absorbs water, and then, as it is saturated with moisture, the rate of penetration of moisture gradually decreases. The endosperm of barley is rich in proteins, harder than the endosperm in which there is more starch. The lower the glassiness, the lower the density of the endosperm, which causes an increase in the rate of water absorption. Barley malt has a powdery structure; therefore, the rate of moisture absorption by it is much higher than that of barley grain.

Barley grain is a capillary-porous colloidal body, which has a cellular structure and many macroand micropores, has sorption properties, that is, it is able to absorb water and its vapor and desorption properties (moisture return), that is, the malt grain is hygroscopic. 


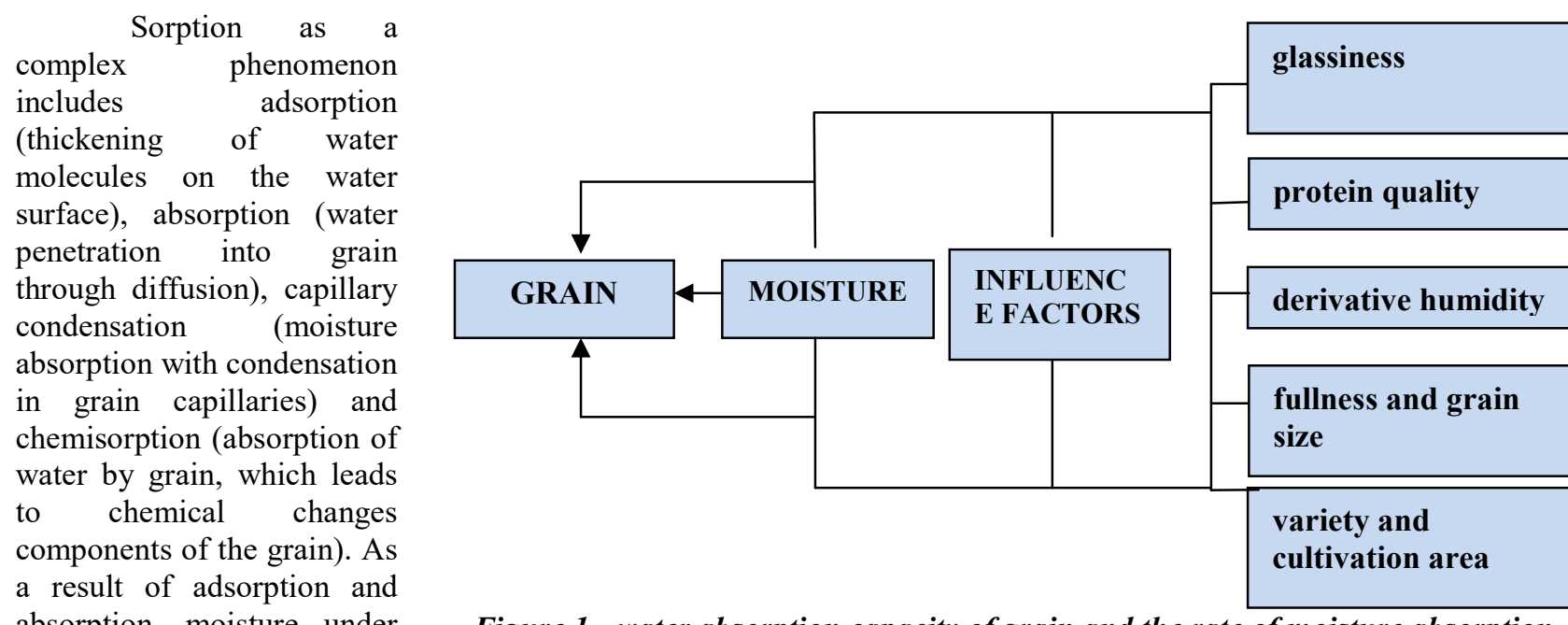
absorption, moisture under the influence of diffusionosmotic forces penetrates deep into the grain and forms solid solutions with colloids, specifically, protein substances, starch, fiber, pentosans, mucus and other high-molecular substances and components of the grain. When swelling, protein substances can absorb up to $250 \%$ or more, starch - 30$35 \%$, mucus up to $800 \%$. Hydrophobic substances, fats and other lipids, soluble in fats pigments, carotenoids, chlorophyll, fat-soluble substances, and others do not swell in water and do not dissolve in it. Some substances of the grain are soluble in water (sugar, free amino acids, phosphates, and others). Substances capable of swelling in water contain $80-85 \%$ in grain [5-6].

Heat effects specifically on the grain, promotes the expansion of capillaries coat and the acceleration of water penetration, which can serve as a catalyst for some phenomena that determine the structural and biochemical changes in the grain and its constituent parts.

Soaking grain raw materials in water is the main way to influence its structure; however, this process can be limited by the destruction of only water-soluble proteins, therefore, chemical solutions are used to break the bonds of starch with other components of the raw materials completely, the choice of the type of which depends on the content of proteins in the grain. As a result, a forced denaturation of proteins occurs, the structure of protein substances changes, which promotes the release of starch grains, and the influence of chemical preparations makes cellular structures penetrated for the diffusion transport of soluble substances in a liquid medium, specifically, into water [7].

The purpose of the study was to determine the optimal modes of hydrothermal processing of dry germinated grains for its further use in the manufacture of food products of the intended destination.

\section{Objectives of the study:}

1. Selection of an optimal hydro module for humidifying barley malt.

2. Determination of optimum temperature regime of hydrothermal malt processing.

3. The study of the degree of swelling of malted grain, followed by the determination of the optimal time of wetting.

\section{Materials and methods of research.}

As a research object, dry germinated grain (malt) produced using a special technology [8-10] according to TU 30664090-001-2012 (MC Ukrsolod LLC) light barley malt was used.

In the work, common methods of research of physicochemical indicators: determination of dry substances, the degree and rate of swelling were used [11].

The degree and rate of swelling of dry germinated grain were determined according to the method of the Belarusian branch of the All-Union Research Institute of Dairy Industry [6]. For this purpose, we took $1 \mathrm{~g}$ of a sample of dry germinated grain, placed it in a centrifuge tube, added distilled water in a ratio of 1:1-1:5. We set temperature parameters and kept in paraconvection apparatus for up to 60 hours. The following temperature parameters were chosen: $25 \pm 1{ }^{\circ} \mathrm{C} ; 35 \pm 1{ }^{\circ} \mathrm{C} ; 45 \pm 1{ }^{\circ} \mathrm{C}$; $55 \pm 1{ }^{\circ} \mathrm{C} ; 65 \pm 1{ }^{\circ} \mathrm{C} ; 75 \pm 1{ }^{\circ} \mathrm{C} ; 85 \pm 1{ }^{\circ} \mathrm{C}$. Further, the test tubes were centrifuged for 5 minutes at $1000 \mathrm{rpm}$. The centrifugate was carefully drained. Moisture content was determined in the residue. The degree of swelling was determined by the formula (1):

$$
\mathrm{A}=\left(\mathrm{m}-\mathrm{m}_{0}\right) * 100 / \mathrm{m}_{0} \text {, }
$$

where $\mathrm{A}-$ the degree of swelling, $\%$;

$\mathrm{m}$ - a mass of grain after hydration, $\mathrm{g}$;

$\mathrm{m}_{0}-\mathrm{a}$ mass of dry grain, $\mathrm{g}$.

The mass of dry germinated grain after swelling was determined by the formula (2):

$$
\mathrm{m}=\mathrm{m}_{0} *(100-\mathrm{B}) /\left(100-\mathrm{B}_{1}\right)
$$

where $\mathrm{m}-$ the mass of the grain after swelling, $\mathrm{g}$

$\mathrm{B}$ - mass fraction of dry grain moisture, $\%$; grain, $\%$.

$\mathrm{B}_{1}$ - a mass fraction of moisture of the hydrated

An optimal hydro module was also determined.

\section{processing of malt and their discussion \\ Since it was researched the hydrothermal} processing of malt, in other words, the grain that has already undergone certain biochemical changes, we should pay attention to the particular water absorption of malt of the different biochemical composition. Table 1 shows the change in the degree of swelling of dry barley 
Table 1 - Change in the degree of swelling of dry germinated barley grain

\begin{tabular}{|c|c|c|c|c|c|c|c|c|}
\hline \multirow{2}{*}{$\begin{array}{l}\text { T, } \\
{ }^{\circ} \mathrm{C}\end{array}$} & \multirow{2}{*}{$\begin{array}{l}\text { Hydro } \\
\text { module }\end{array}$} & \multicolumn{7}{|c|}{ Degree of swelling } \\
\hline & & $1 \mathrm{~h}$ & $3 \mathrm{~h}$ & $6 \mathrm{~h}$ & $12 \mathrm{~h}$ & $24 \mathrm{~h}$ & $48 \mathrm{~h}$ & $60 \mathrm{~h}$ \\
\hline 1 & 2 & 3 & 4 & $\overline{5}$ & 6 & 7 & 8 & 9 \\
\hline \multirow{5}{*}{25} & $1: 1$ & 12 & 13 & 26 & 35 & 47 & 53 & 50 \\
\hline & $1: 2$ & 13 & 14 & 32 & 39 & 50 & 54 & 51 \\
\hline & $1: 3$ & 18 & 20 & 36 & 40 & 50 & 55 & 53 \\
\hline & $1: 4$ & 20 & 22 & 39 & 44 & 52 & 56 & 54 \\
\hline & $1: 5$ & 19 & 21 & 37 & 41 & 51 & 52 & 51 \\
\hline \multirow{5}{*}{35} & $1: 1$ & 30 & 43 & 55 & 67 & 84 & 92 & 88 \\
\hline & $1: 2$ & 32 & 45 & 64 & 70 & 89 & 99 & 93 \\
\hline & $1: 3$ & 33 & 48 & 68 & 73 & 95 & 105 & 96 \\
\hline & $1: 4$ & 35 & 50 & 72 & 78 & 98 & 112 & 99 \\
\hline & $1: 5$ & 31 & 47 & 69 & 75 & 93 & 107 & 92 \\
\hline \multirow{5}{*}{45} & $1: 1$ & 48 & 71 & 90 & 100 & 120 & 122 & 118 \\
\hline & $181: 2$ & 20 & $7 \overline{75}$ & 888 & 90 & 122 & 125 & 121 \\
\hline & $1: 3$ & 52 & 78 & 89 & 91 & 127 & 140 & 131 \\
\hline & $1: 4$ & 52 & 79 & 89 & 91 & 126 & 132 & 128 \\
\hline & $1: 5$ & 49 & 73 & 83 & 89 & 121 & 127 & 125 \\
\hline \multirow{5}{*}{55} & $1: 1$ & 53 & 75 & 112 & 126 & 132 & 141 & 138 \\
\hline & $1: 2$ & 256 & 81 & 1118 & 130 & 142 & 156 & 151 \\
\hline & $1: 3$ & 57 & 87 & 121 & 134 & 154 & 168 & 163 \\
\hline & $1: 4$ & 60 & 93 & 123 & 138 & 157 & 176 & 170 \\
\hline & $1: 5$ & 55 & 87 & 117 & 131 & 152 & 173 & 168 \\
\hline \multirow{5}{*}{65} & $1: 1$ & 60 & 80 & 125 & 142 & 145 & 160 & 153 \\
\hline & $1: 2$ & 63 & 83 & 142 & 153 & 170 & 180 & 178 \\
\hline & $1: 3$ & 65 & 110 & 145 & 160 & 185 & 191 & 188 \\
\hline & $1: 4$ & 66 & 100 & 146 & 168 & 189 & 194 & 189 \\
\hline & $1: 5$ & 61 & 93 & 141 & 163 & 184 & 193 & 187 \\
\hline \multirow{5}{*}{75} & $1: 1$ & 56 & 75 & 105 & 112 & 131 & 142 & 139 \\
\hline & $1: 2$ & 58 & 79 & 111 & 123 & 146 & 147 & 145 \\
\hline & $1: 3$ & 259 & 86 & 1115 & 128 & 151 & 153 & 151 \\
\hline & $1: 4$ & 60 & 93 & 118 & 131 & 154 & 158 & 153 \\
\hline & $18: 5$ & 257 & 89 & 1113 & 127 & 153 & 151 & 145 \\
\hline \multirow{5}{*}{85} & $1: 1$ & 50 & 72 & 78 & 80 & 120 & 125 & 123 \\
\hline & $1: 2$ & 52 & 74 & 79 & 88 & 124 & 128 & 124 \\
\hline & $1: 3$ & 53 & 78 & 84 & 91 & 130 & 142 & 135 \\
\hline & $1: 4$ & 54 & 81 & 90 & 100 & 128 & 130 & 124 \\
\hline & $1: 5$ & 51 & 75 & 84 & 95 & 121 & 127 & 121 \\
\hline
\end{tabular}

malt, depending on the hydro module, temperature regime and moisture time.

At the beginning of the process, the malt is moistened independently of the temperature. Despite the temperature fluctuations, the amount of moisture contained in the malted grain is almost unchanged. Subsequently, the penetration of moisture, which is retained by the forces of surface tension, is characterized by an intensive absorption of moisture by the coats and internal parts of the malted grain. At this stage, the effect of temperature is already more noticeable and the rate of water absorption is already increasing at a temperature of $45^{\circ} \mathrm{C}$.

All moisture in the grain is physically and chemically bound, this aspect has a great technological significance. So, when the usual conditions change, in our case this is a change in the temperature regime, there is a change in the dynamic balance, as a result, more active transport of moisture to the malted grain occurs. An increase in temperature has particular importance in this process, with this there is a partial destruction of the bonds of adsorbed water molecules, and some of them are desorbed, whereby free moisture is formed. Due to the structural features of the malted grain, it is quite difficult to release moisture into the environment. Weakly bound moisture affects the physical and chemical properties of biopolymers, causes an increase in the flexibility and mobility of the protein chains of their micromolecules. Along with the expansion of intermolecular gaps, there is a decrease in the density and hardness of malted grain, which affects the nature of its deformation.

An important aspect is the amount of water that is involved in the wetting of the grain material, specifically, malt. So we studied the water absorption at five different hydro modules. The data is shown in Fig. 2-6.

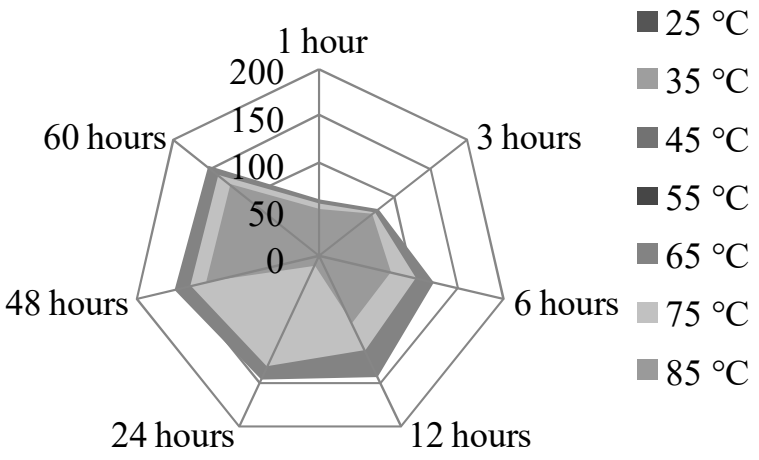

Figure 2 - Hydro module 1:1

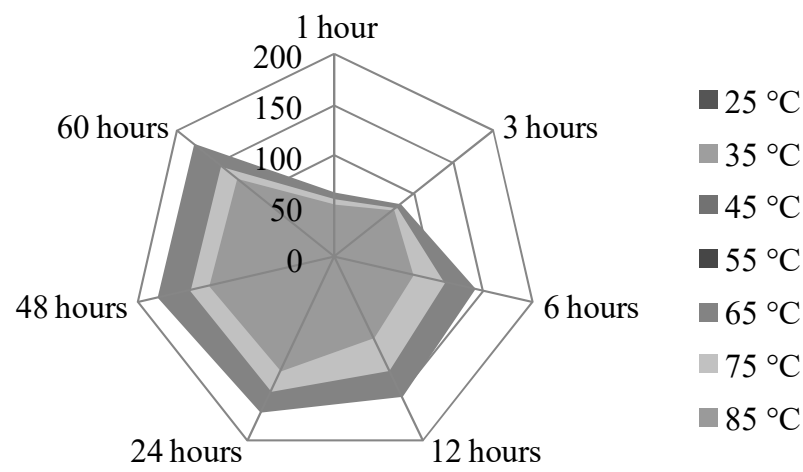

Figure 3 - Hydro module 1:2 


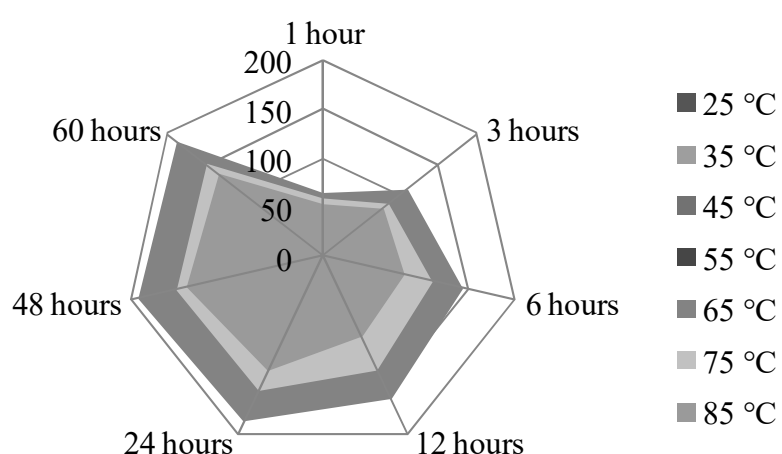

Figure 4-Hydro module 1:3

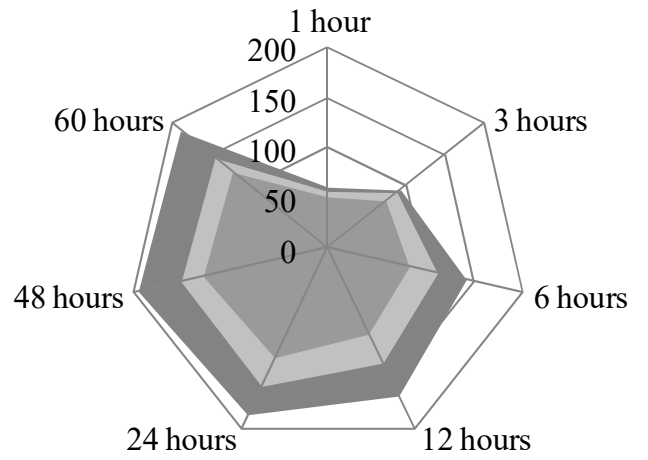

$\square 25^{\circ} \mathrm{C}$

$-35^{\circ} \mathrm{C}$

$45^{\circ} \mathrm{C}$

$\square 55^{\circ} \mathrm{C}$

$65^{\circ} \mathrm{C}$

$75^{\circ} \mathrm{C}$

$85^{\circ} \mathrm{C}$

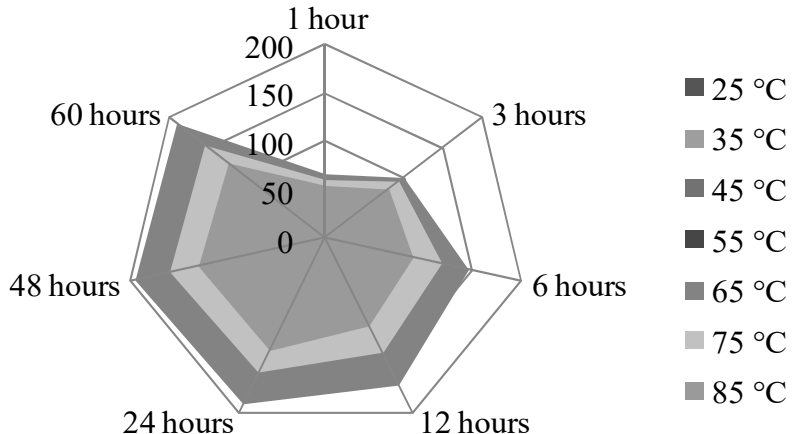

Figure 5-Hydro module 1:4

volume of water spent on soaking the grain material before its further use in the process.

The time of interaction with moisture during hydrothermal processing has a great influence on all processes occurring in grain. Over time, there is a change in the intensity of moisture transport from the coat into the endosperm. The diffusion coefficient of moisture decreases, which has great practical importance for increasing the efficiency of hydration.

Approvement of research results. All studies were performed on the basis of the Scientific and Production Laboratory for the determination of the quality of grain and grain products of the Dnipro State Agrarian and Economic University.

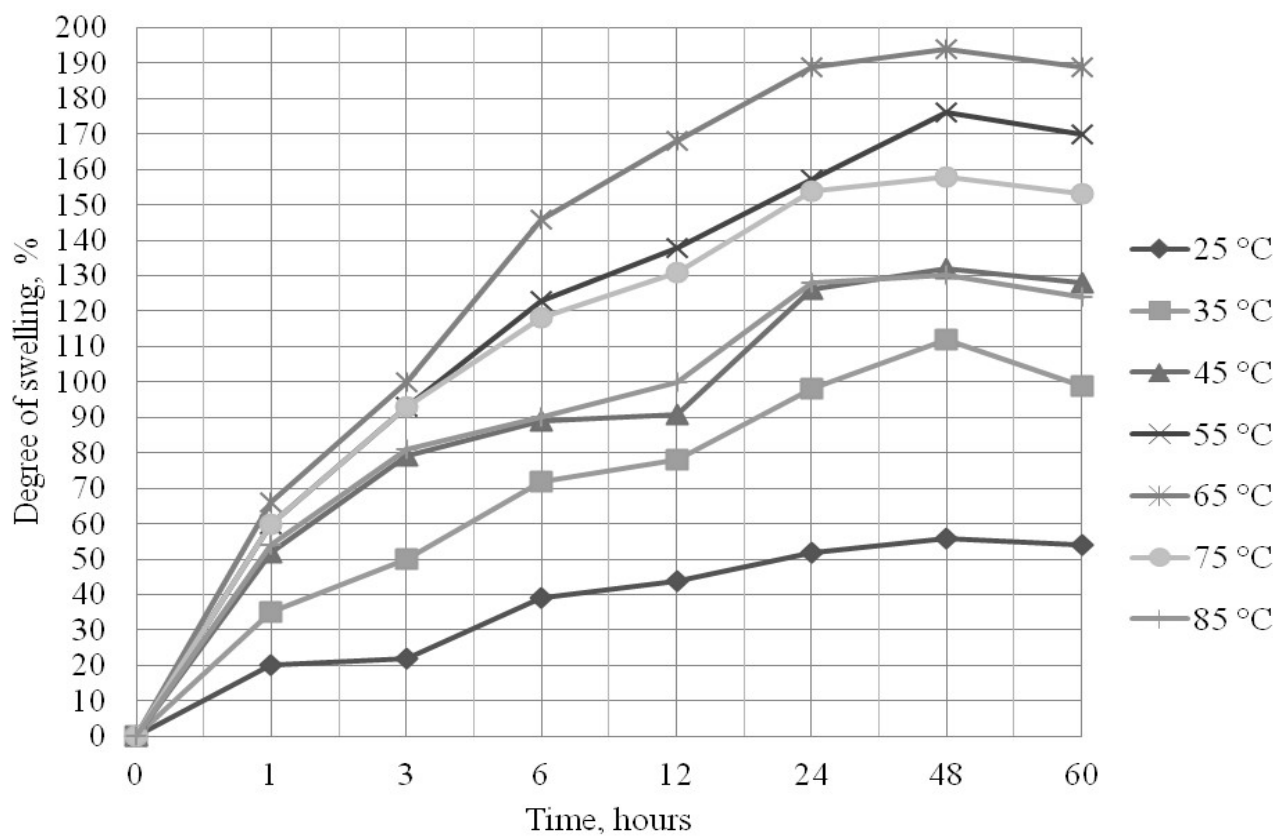

Figure 7 - Dependence of the degree of swelling of malt on the time of hydrothermal processing at the optimal hydro module 1:4

Analyzing the data obtained, we can conclude that the optimal hydro module is $1: 4$. In this mode, the maximum values of the degree of swelling are observed.

Fig. 7 shows a graph which depicts the dependence of the degree of swelling of the grain on the time of hydrothermal processing, specifically, at the optimum hydro module. The dynamics of changes in water absorption activity at this hydro module has the highest values, which indicates the correctness of the selection of the ratio of the amount of malt and the
The optimal parameters of hydrothermal processing of barley malt, which were selected in laboratory conditions, can be introduced into production at any enterprise specializing in manufactured malt food products.

\section{Conclusions.}

1. In a deep analysis of the data obtained, it can be concluded that the optimal hydro module for swelling barley malt is $1: 4$. mum temperature regime of hydrothermal malt processing was $+65^{\circ} \mathrm{C}$.

3. In the study of the degree of swelling of malted grain, the duration of hydrothermal processing, which was 48 hours, was determined,

Thus, it was proposed modes of hydrothermal processing of barley malt for its further use in the production of various food products. The regimes of hydrothermal processing of barley malt presented will allow optimizing the technological process of malt processing.
2. The opti- 


\section{REFERENCES}

1. Narcis L. Brewing. Technology of malting. SPb .: The profession, 2007. $584 \mathrm{p}$.

2. $\quad$ Narcis L. Short course of brewing. SPb. : Profession, 2007. 640 .

3. Meledina T.V. Raw materials and auxiliary materials in brewing SPb ..: Profession, 2003. $304 p$.

4. Kunze V., Mit G. Technology of malt and beer. SPb. : Profession, 2007. 520 pp.

5. Egorov G.A. Effect of heat and moisture on the processes of grain processing and storage. Moscow: Kolos, 1973. $264 p$.

6. Safronova T.M, Evtukhova O.M, Farinkova I.V. A new type of functional additive in food products // Vestnik KrasAAU. 2013. № 6. P.183-189.

7. Bulgakov N.I. Biochemistry of malt and beer. M.: Food Industry, 1976. 360 p.

8. Pivovarov O.A, Kovaleva O.S., Chursinov Yu.O. Malt production using activated non-equilibrium plasma aqueous solutions // Bulletin of the Dnepropetrovsk State Agrarian University. 2009. №2. P. 194-197.

9. Pivovarov O.A, Kovalyova O.S. Investigation of Adsorption Properties of Grain Using Aqueous Solution Processed by Contact Non-Equilibrium Plasma // Problems of Chemistry and Chemical Technology. 2011. №5. Pp. 18-21.

10. Influence of plasma-chemically activated aqueous solutions on the processes of adsorption and desorption of grain material in the production of malt / Pivovarov A.O. // Storage and processing of grain. 2013, No. 9 (174). P. 56-60.

11. Meletyev A.E Technochemical control of malt, beer and soft drinks production / Meletyev A.E, Todosyuchuk S.R, Koshova V.M. : ed. A.E.Meletyev (Textbook). - Vinnitsa: The New Book, 2007. - 392 p.

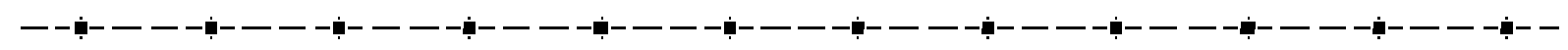

О.С. КОВАЛЬОВА, канд. техн. наук, доцент,

Ю.О. ЧУРСІНОВ, д-р техн. наук, професор,

Д.Д. КОФАН, магістрант

ДОСЛІДЖЕННЯ ГІДРовский державний аграрноеекономічний ун СУХОГО ЯЧМІННОГО СОЛОДУ

\section{Анотація}

Функиіональні властивості харчових продуктів з додаванням пророслої зернової сировини стали об'єктом підвищеної уваги вчених і фахівців харчової промисловості. Крім харчових інгредієнтів, харчові продукти з додаванням зернової сировини містять функціональні інгредієнти, які позитивно впливають на організм людини, щзо допомагає адаптуватися до впливу зовнішнього середовища. Функиіональні продукти з додаванням пророщеного зерна розглядаються не тільки як джерело пластичних речовин $і$ енергї̈, але $і$ як живильний комплекс, щзо забезпечує лікувальний ефект.

Використання пророщеного зерна в харчовій та переробній промисловості є дуже обмеженим через його короткий термін зберігання та характеристики приготування солоду для подальшої переробки. Відповідним технологічним завданням є вибір режимів вологості ячмінного солоду.

Здійснено иикл досліджень щуодо гідротермічної обробки сухого ячмінного солоду. Метою визначення оптимальних технологічних режимів гідротермічної обробки сухого пророщеного зерна є перспективи його подальшого використання в різних харчових технологіях як харчова добавка або компонент збагачення продуктів біологічно активними речовинами.

У роботі висвітлено процес відбору та основні технологічні параметри процесу, які можуть бути використані при промисловій переробиі ячмінного солоду. Як об'єкт дослідження використовувався сухий пророщений зерно (солод), вироблений за спеціальною технологією. В ході дослідження було обрано оптимальний гідромодуль для зволоження ячмінного солоду, визначено температурний режим гідротермічної обробки пророщченого зерна, визначено ступінь набухання солодового зерна, оптимальний час змочування сировини для його подальшого обробку визначали.

При аналізі отриманих даних було зроблено висновок, щуо оптимальним гідромодулем для набухання ячмінного солоду є 1: 4, оптимальна температура - $+65^{\circ} \mathrm{C}$, тривалість гідротермічної обробки - 48 годин. Представлені в статті режими гідротермічної обробки ячмінного солоду дозволять оптимізувати технологічний процес переробки солоду.

Ключові слова: ячмінь, солод, пророщене зерно, волога, гідротермічна обробка, ступінь набухання, ивидкість набухання, гідромодуль.

\section{ЛITЕРАТУРА}

1. Нариис Л. Пивоварение. Технология солодоращения. СПб.: Профессия, 2007. 584 c.

2. Нариис Л. Краткий курс пивоварения. СПб. : Профессия, 2007. 640 с.

3. Меледина Т. В. Сырье и вспомогательные материалы в пивоварении СПб.: Профессия, 2003. 304 c.

4. Кунце В., Мит Г. Технология солода и пива. СПб. : Профессия, 2007. 520 с.

5. Егоров Г.А. Влияние тепла и влаги на процессы переработки и хранения зерна. Москва: Колос, 1973. 264 с.

6. Сафронова Т.М., Евтухова О.М., Фаринкова И.В. Новый вид функциональной добавки в пищевые продукты // Вестник КрасГАУ. 2013. №6. С.183-189.

7. Булгаков Н.И. Биохимия солода и пива. М. : Пищевая промышленность, 1976. 360 с.

8. Півоваров О.А., Ковальова О.С., Чурсінов Ю.О. Виробництво солоду з використанням активованих під дією нерівноважної плазми водних розчинів // Вісник Дніпропетровського державного аграрного університету. 2009. №2. C. 194-197. 
9. Півоваров О.А., Ковальова О.С. Дослідження адсорбиійних властивостей зерна при використанні водних розчинів, оброблених контактною нерівноважною плазмою // Вопросы химии и химической технологии. 2011. №5. C.18-21.

10. Вплив плазмохімічно активованих водних розчинів на процеси адсорбцї та десорбції зернового матеріалу у виробництві солоду / Півоваров А.О. // Хранение и переработка зерна. 2013. №9(174). С.56-60.

11. Мелетьєв А.С. Технохімічний контроль виробництва солоду, пива і безалкогольних напоїв / Мелетьєв А.С., Тодосійчук С.Р., Кочова В.М. : за ред. А.С.Мелетьєва. (Підручник). - Вінниия : Нова Книга, 2007. - 392 с.

Надійшла 28.08.2018. До друку 12.09.2018. Рецензія 29.08.2018

Адреса для переписки:

E-mail: livre@i.uaE-mail: tzpsgp@,i.ua E-mail: denkofan@gmail.com

* Department of Technology Storage and Processing of Agricultural Products

Dnipro State Agrarian and Economic University 25 Serhiia Yefremova Street, Dnipro, 49600, Ukraine

\title{
PROSPECTS FOR THE USE OF GRAIN RAW MATERIALS IN THE PRODUCTION OF FUNCTIONAL PRODUCTS
}

\begin{abstract} prove the organoleptic properties of bakery, dairy and confectionery. johnsonii, L. plantarum, Bifidobacterium longum, B. breve, B. lactis. metic industries. pharmaceutical industry. functionality of which must be studied.

Interest in the development of technologies for the production of functional products is growing due to their high market potential, which is associated with a number of their protective properties. Functional foods contain substances that have a positive effect on the human body, which makes them the subject of scientific research. Special attention in the development of functional products is paid to increasing their industrial production from various types of raw materials. This approach allows the development of functional products based on regional resources [1-3]. The term "functional nutrition" in the scientific literature appeared in Japan in 1989, the main approaches to the definition of which correspond to three characteristics: forming part of the daily diet; components must be natural (of natural origin); along with the nutritional value should contribute to the regulation of any function of the body. The creation and introduction of functional products into produc-
\end{abstract}

The development of new physiologically functional food products is a prospective direction for world food products market. The inclusion of functional ingredients in food can increase the biological value of products that are already familiar to the consumer, as well as expand the range of products offered. Physiological activity of cereal's ingredients varies widely, there are: anticancer, antiallergic, antioxidant properties, prebiotic, immunostimulating effects, etc. Moreover, the cereal's ingredients can im-

Cereals can be used as a prebiotics: fermentable substrates for the growth of probiotic microbiota. It is scientifically proven that grain's nondigestible carbohydrates stimulate the growth of Lactobacillus acidophilus, L. casei, L. reuteri, L. rhamnosus, $L$.

Cereals contain water-soluble fibre, such as $\beta$-glucan and arabinoxylan, oilgosaccharides, such as xylo- and fructooligosaccharides and resistant starch, which have a wide application as prebiotic preparations. Furthermore, cereals as wheat, rye and rice contain polyphenols (benzoic and cinnamic acid derivatives) that are used both in the food industry as antioxidants, dyes, flavors of natural origin and in the compositions of physiologically functional ingredients, as well as in the pharmaceutical and cos-

Thus using cereals as a raw material for functional ingredients obtaining is a perspective in biotechnology, food and

The modification of cereals processing technologies also will allow produce insufficiently studied prebiotic compounds, the

Keywords: cereals, probiotics, prebiotics, modified polysaccharides, functional products

tion is one of the areas of the humanistic program of human nutrition proclaimed by the UN $[1,2]$.

The use of biologically active additives (BAA) allows filling the shortage of essential nutrients, increasing the nonspecific resistance of the organism to the effects of adverse factors, carrying out immune correction, individualizing the most nutrition. Among the existing dietary supplements, widespread and rapid development are observed among probiotics and prebiotics.

Probiotic products are defined as products that contain a single or mixed culture of microorganisms that positively affect the health of consumers and correct the balance of the intestinal microbiota [20]. Their physiological effect has been widely studied by domestic and foreign scientists both in vitro studies and through clinical animal tests, namely lactose metabolism, control of gastrointestinal infections, suppression of cancer, reduction of serum cholesterol and immune stimulation $[19,24]$. In probiotic preparations, mainly the following 